\title{
Heavy Metals Content in Phaeophyceae from Malang Rapat Waters, Bintan
}

\author{
Hilda Novianty ${ }^{\star}{ }^{*}$ Emienour Muzalina Mustafa ${ }^{2}$, Suratno $^{1}$ \\ ${ }^{1}$ Research Division for Natural Product Technology, Indonesian Institute of Sciences \\ Jl. Jogja Wonosari Km 31.5, Gading, Playen, Gunungkidul, Yogyakarta 55861 \\ ${ }^{2}$ Faculty of Fisheries and Food Science, Universiti Malaysia Terengganu \\ Kuala Nerus, Terengganu, Malaysia 21030 \\ Email: hildanovianty2012@gmail.com
}

\begin{abstract}
The use of brown-macroalgae (Phaeophyceae) as an alginate source is very broad, covering the food and non-food industry, because of that it is necessary to know the safety of these natural resources, one of which is safe from heavy metal contamination. The purpose of this study was to determine heavy metals concentrations accumulated in several types of Phaeophyceae (brown macroalgae) as an alginate source from Malang Rapat waters, Bintan. The method used was descriptive non-experimental. The determination of the location of sampling was done by purposive sampling method. Samples were taken through free collection, identified species and measured of metal contamination concentrations for $\mathrm{As}, \mathrm{Cd}$, and $\mathrm{Pb}$. The data obtained were analyzed descriptively. The results showed that Phaeophyceae found in Malang Rapat waters were Turbinaria conoides, Sargassum aquifolium, Padina australis, Hormophysa cuneiformis with each metal concentration contamination of As 13.95 to $23.30 \mu \mathrm{g} . \mathrm{g}$ ${ }^{1}$ dry weight; Cd from 0.33 to $1.08 \mu \mathrm{g} \cdot \mathrm{g}^{-1} \mathrm{dry}$ weight and Pb from 4.72 to $9.92 \mu \mathrm{g} \cdot \mathrm{g}^{-1} \mathrm{dry}$ weight. This study showed that all metal contamination ranges in all Phaeophyceae were on the verge of the maximum limit set by the National Standardization Agency of Indonesia Indonesian (SNI) No 7387 of 2009 and National Agency of Drug and Food Control of RI (BPOM) Regulation No 5 of 2018 for dried macroalgae product so that Phaeophyceae from Malang Rapat waters - Bintan was not safe to be used as raw material for alginate source or other processed products of brown-macroalgae.
\end{abstract}

Keywords: Phaeophyceae; macroalgae; heavy metal; coastal; Malang Rapat

\section{Introduction}

Food safety is the main priority in using natural resources as the main raw material in the manufacture of food or non-food products. The flow of the food safety process begins from the source of the raw materials used. One of the natural resources that have the potential to be used as a food or nonfood product is Phaeophyceae (brown macroalgae) which contain secondary metabolites that are beneficial to health, including alkaloid compounds, glycosides, tannins, and steroids which are widely used in medicine and pharmacy industry (Gazali et al., 2018). Mostly, Phaeophyceae are found in the coastal areas of Indonesia, which are Sargassum, Turbinaria, Cystoseira, Dictyopteris, Dictyota, Hormophysa, Hydroclathrus, and Padina (Atmadja, 1996), one of the coastal area is Malang RapatBintan. In these waters, many types of Phaeophyceae are found and have not been utilized. The safety of raw resources utilization is needed to make high quality of the product.

Phaeophyceae is also known as a source of alginate powder, which has functional properties such as thickener, emulsifier, stabilizer, film-forming, gelling agent (Maharani et al., 2017), where it can be used as edible coating or edible film for food products (Parreidt et al., 2018) and the non-food product were used for medicinal products, cosmetics, paints, ceramics, and insecticides (Prasetyaningrum and Purbasari, 2002). Alginate is an extracted product from Phaeophyceae. The application of Phaeophyceae or its extract should be safe for human, and the use of the raw materials must also safe from any contamination.

The regulation of National Standardization Agency of Indonesia No. 7387 of 2009 explains that contaminated foods are those that contain contaminants exceed the maximum predetermined threshold (National Standardization Agency of Indonesia, 2009). One of the contamination entry factors into raw materials are through their surrounding environment. Source of water contamination could be from human activities, which are household waste, industry, and tourism activities, where the coastal area of Malang Rapat-Bintan has a variety of activities as mentioned above. Tourism activities in the Bintan Regency area have the largest source of contamination from plastic waste by 48.56\% (Mulyadi et al., 2017). Part of Bintan area is
*) Corresponding author

(c) IImu Kelautan, UNDIP DOI: 10.14710/ik.ijms.26.1.57-62
Received : 04-09-2020

Accepted : 15-01-2021 
also explored for natural resources such as bauxite, granite, sand, andesite, quartz sand (Rohmana et al., 2007), where mining activities can cause environmental pollution. Macroalgae that live in a coastal area can be polluted through the environment, including heavy metals contamination. Heavy metals are dangerous for humans because they are toxic if it presents in large quantities in the body (Ismarti et al., 2017).

Heavy metal pollution enters the coastal area through river flow intake and will be dissolved in water and accumulated in sediment, which would increase over time (Setiawan, 2013). This causes macroalgae, which is lived by attached to the substrate and absorbs nutrients substances from the waters through its body surface (thallus), it will be contaminated and accumulated in their bodies. Macroalgae are known to have the ability to absorb heavy metals which are connected to their natural lifestyle which attached themselves to the substrate of mud, sand, coral, rock, or wood which settles on the bottom of the waters and then is absorbed into the macroalgae tissue and eventually accumulates in the thallus, and the bioaccumulation process occurs intensively (Manalu, 2017).

Heavy metal contamination could be from Arsenic (As), Cadmium (Cd), and Lead (Pb). The maximum limit for those heavy metal contamination for dried macroalga products are shown in Table 1 (National Standardization Agency of Indonesia, 2009). The toxicity of heavy metals that enter the human body through their food will cause detoxification, excretion (liver and kidney) tissue damage, and can lead to cancer potential gradually (Agustina, 2014). Information on heavy metal contamination in brown macroalgae in the waters of Malang Rapat-Bintan is not yet available from the previous study. This study aims to determine the concentration of heavy metals that have accumulated in several types of Phaeophyceae (brown macroalgae) which have the potential as a source of alginate from the waters of Malang Rapat - Bintan.

\section{Material and Methods}

Brown macroalgae were collected from surrounding waters of Malang Rapat-Bintan in April 2019 during low tide $(0-10 \mathrm{~cm})$. The map of the sampling location area is shown in Figure 1. Macroalgae were collected in $1.5 \mathrm{~m}$ areas in the right and left of $100 \mathrm{~m}$ of roll meter upright of coastal line. Samples were collected by purposive sampling method since the area has the potential brown macroalgae used for alginate powder production and has the possibility of the contamination. Macroalgae in the same species directly soaked with seawater on the area to remove debris.

The samples collected were kept in plastic ziplock bag, labeled for species identification and heavy metal measurement, before being put into a cooler box and bringing it back to the laboratory. In the laboratory, the samples were store in freezer $\left(-20^{\circ} \mathrm{C}\right)$ before analysis were conducted. Samples were identified for its species and dried in oven at $60^{\circ} \mathrm{C}$ for $24 \mathrm{~h}$, before it was grounded into powder by using a mortal for measurement of heavy metals (As, $\mathrm{Cd}, \mathrm{Pb})$ content.

Measurement of heavy metals was carried out in the laboratory of Occupational Health and Safety Advisory Services Jakarta, Ministry of Health of Republic of Indonesia. The method to measure it was referred to Bowen (2009). Dried samples were made into powder and then weighed as much as 0,4-0,5 g. Replicate the sample three times for one species. After being weighed, the samples were put in a Teflon vessel and added $5 \mathrm{ml}$ of distilled water and $5 \mathrm{ml}$ of $\mathrm{HNO}_{3}$ and then put it in the microwave for $2 \times 20$ minutes at $185^{\circ} \mathrm{C}$. After the heating process was complete, the sample is removed and left it in the room temperature and then transferred to a $25 \mathrm{ml}$ volumetric flask and then added distilled water until the measuring limit of $25 \mathrm{ml}$. Filtered the solution through filter paper to make the solution is free from particles that can be interfered with the measurement process and then measured by using an Inductively Coupled Plasma with Optical Emission Spectrometer (ICP-OES Thermo 7400). Method Detection Limit (MDL) of instrumentation for As, Cd and $\mathrm{Pb}$ were $0.0021 \mathrm{mgL}^{-1}, 0.0003 \mathrm{mg} . \mathrm{L}^{-1}$ and 0.0013 mg.L-1 respectively. Method of Quantification Limit (MQL) of instrumentation for $\mathrm{As}, \mathrm{Cd}$ and $\mathrm{Pb}$ were $0.0071 \mathrm{mg} . \mathrm{L}^{-1}, 0.0008 \mathrm{mg} . \mathrm{L}^{-1}$ and $0.0044 \mathrm{mg} . \mathrm{L}^{-1}$, respectively. Internal standard of $\mathrm{As}, \mathrm{Cd}$ and $\mathrm{Pb}$ were used as spike to validate and standardization the methods with recovery results for As $91.04 \pm 0.7 \%, \mathrm{Cd}$ $86.12 \pm 0.5 \%$ and $\mathrm{Pb} 102.28 \pm 1.0 \%$, respectively.

Table 1. The maximum limit of heavy metal contamination for dried macroalgae

\begin{tabular}{ccccc}
\hline No & $\begin{array}{c}\text { Contaminated } \\
\text { heavy metal }\end{array}$ & Product & $\begin{array}{c}\text { Max limit } \\
\text { National Standardization Agency of } \\
\text { Indonesia (2009) }\end{array}$ & $\begin{array}{c}\text { Max limit } \\
\text { National Agency of Drug and } \\
\text { Food Control of RI (2018) }\end{array}$ \\
\hline 1. & Arsenic $(\mathrm{As})$ & Dried & $1.0 \mathrm{mg} \cdot \mathrm{kg}^{-1}$ & $1.0 \mathrm{mg} \cdot \mathrm{kg}^{-1}$ \\
2. & Cadmium $(\mathrm{Cd})$ & macroalgae & $0.2 \mathrm{mg} \cdot \mathrm{kg}^{-1}$ & $0.05 \mathrm{mg} . \mathrm{kg}^{-1}$ \\
3. & Lead $(\mathrm{Pb})$ & & $0.5 \mathrm{mg} \cdot \mathrm{kg}^{-1}$ & $0.20 \mathrm{mg} \cdot \mathrm{kg}^{-1}$ \\
\hline
\end{tabular}


Data from the measurement of heavy metal content ( $\mathrm{As}, \mathrm{Cd}, \mathrm{Pb})$ in various brown macroalgae types were tabulated and analyzed descriptively. The results of metal contamination of this study were compared with the limit of metal contamination measured for dried macroalgae product based on the regulation of National Standardization Agency of Indonesia No. 7387 of 2009 and National Agency of Drug and Food Control of Republic of Indonesia (2018) (Table 1).

\section{Result and Discussion}

The types of Phaeophyceae were found in the waters of Malang Rapat-Bintan were Turbinaria conoides, Sargassum aquifolium, Padina australis, Hormophysa cuneiformis, which had potential as a source of alginate (Atmadja, 1996). These macroalgae are widely used as raw materials in the industrial sector for food, pharmacy, cosmetics, feed, fertilizers, textiles, and paper (Pakidi and Suwoyo, 2016). Waters of Malang Rapat-Bintan has abundant of Phaeophyceae. However, the location sampling area surroundings have the potential for pollution input from resident, tourism, and mining activities sector so that it will lead to the possibility of intake of contaminants into the coastal area environment. Meanwhile, the safety of Phaeophyceae utilization, it is necessary to know the heavy metal contaminants in it. The discussion about this study result will be described in this session.

The results of Arsenic (As) metal contamination was found in those samples were shown in Figure 2 and Table 2, which ranged between 13.95 to $23.30 \mu g . g^{-1}$ in dried weight. All of the As concentration for all samples have been above the threshold as referred to Table 1. It indicated that the dried macroalgae is not safe yet to be used as a food raw material content. As contamination in the environment can originated from volcanic eruptions and industrial activities (metallurgy, glass factories, production of colour materials, and industries that produce arsenic) (Agustina, 2014). Excess As in the body will be lead to a decrease in the ability of locomotion coordination, disorders of the nerves, breathing, and kidneys (Suhendrayatna, 2001).

Figure 3 and Table 2 showed the amount of $\mathrm{Cd}$ metal content in various types of Phaeophyceae that were found in the waters of Malang Rapat- Bintan, ranged between 0.33 to $1.08 \mu g . g^{-1}$ in dried weight. The amount of $\mathrm{Cd}$ metal content in Phaeophyceae was above the maximum threshold for dried macroalgae products based on Table 1 . This indicates that Phaeophyceae is contaminated and is not safe yet to be used as raw material for alginate powder or other food processing. Cd metal contamination can come from volcanic eruptions, forest fires, industrial waste, the use of fertilizers and pesticides, metal coating and smelting, dyeing, batteries, and the fuel industry (Agustina, 2014). If the $\mathrm{Cd}$ metal concentration in the human body exceeds the threshold, it will lead to a risk of blood vessels, resulting in lung disorders, emphysema, and chronic renal tubular disease (Suhendrayatna, 2001).

Figure 4 and Table 2 showed the concentration of $\mathrm{Pb}$ in several of Phaeophyceae were found in the waters of Malang Rapat-Bintan were ranged from 4.64 to $9.92 \mu \mathrm{g} . \mathrm{g}^{-1}$ in dried weight. All samples were above the maximum threshold for $\mathrm{Pb}$ contamination based on Table 1 for dried macroalgae products.

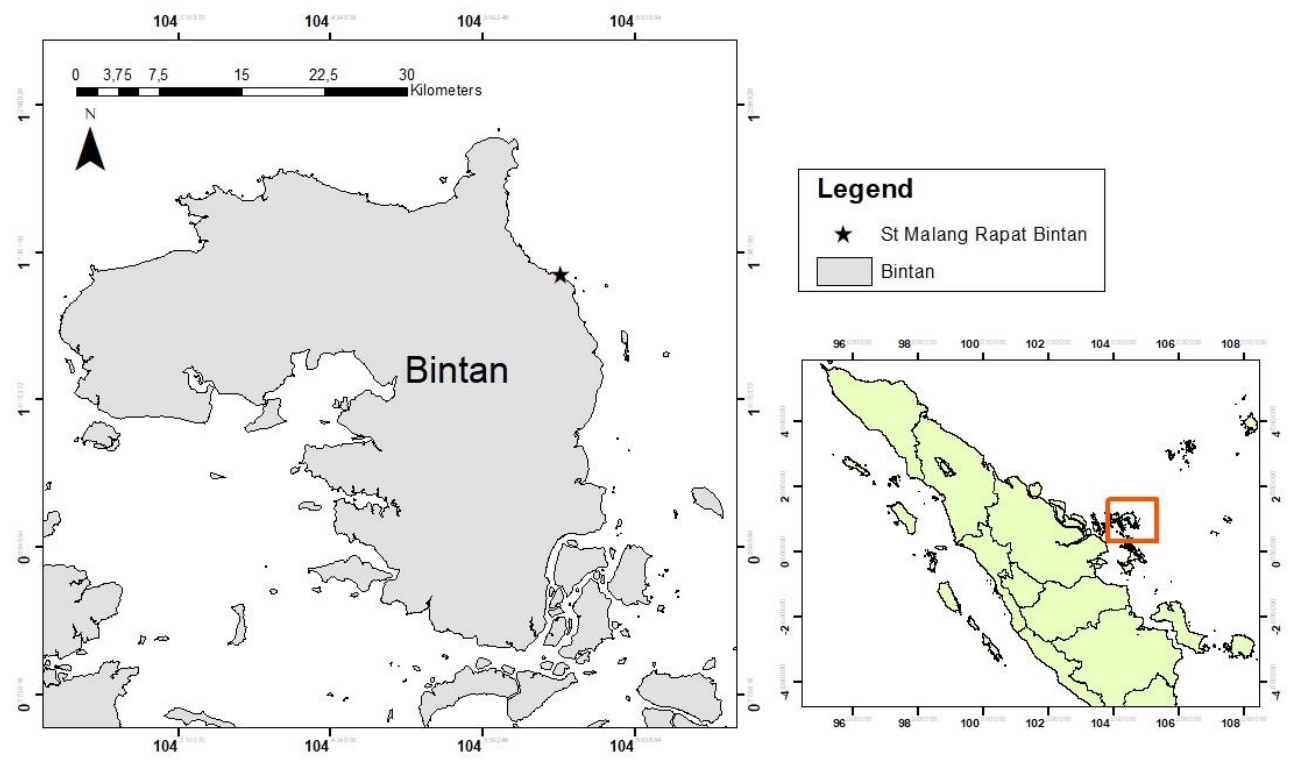

Figure 1. Map of Malang-Rapat, Bintan, showing collection site of Phaeophyceae sample with $\star$ sign 


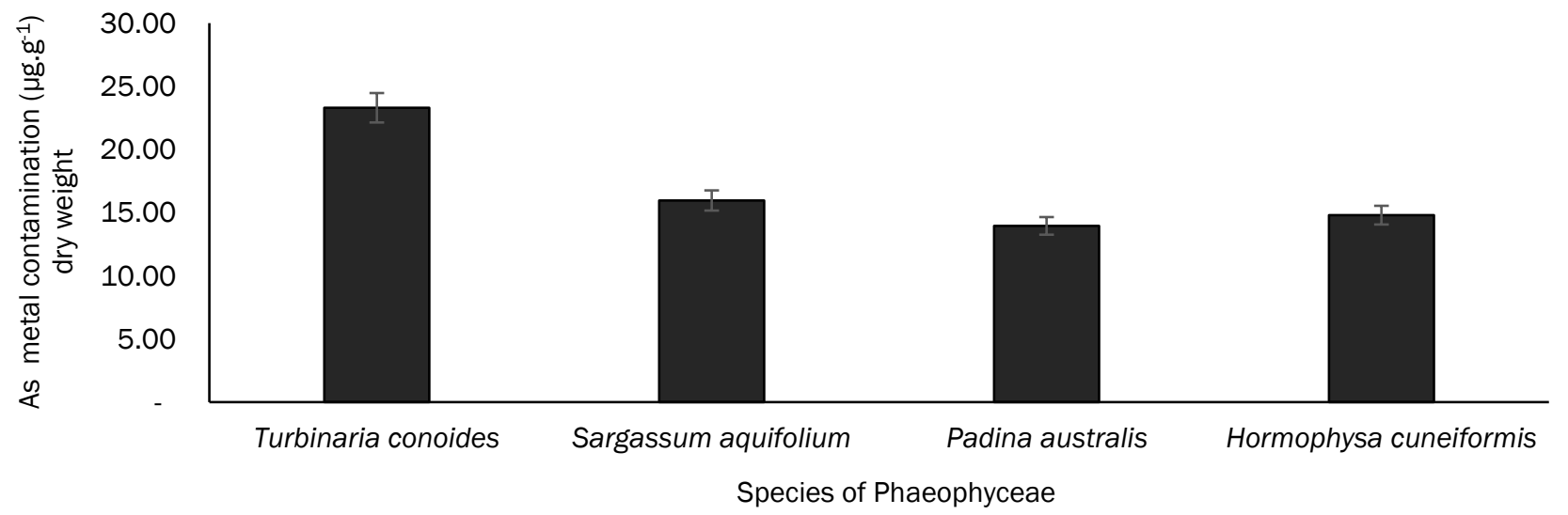

Figure 2. Content of As heavy metal in several of Phaeophyceae from Malang Rapat waters

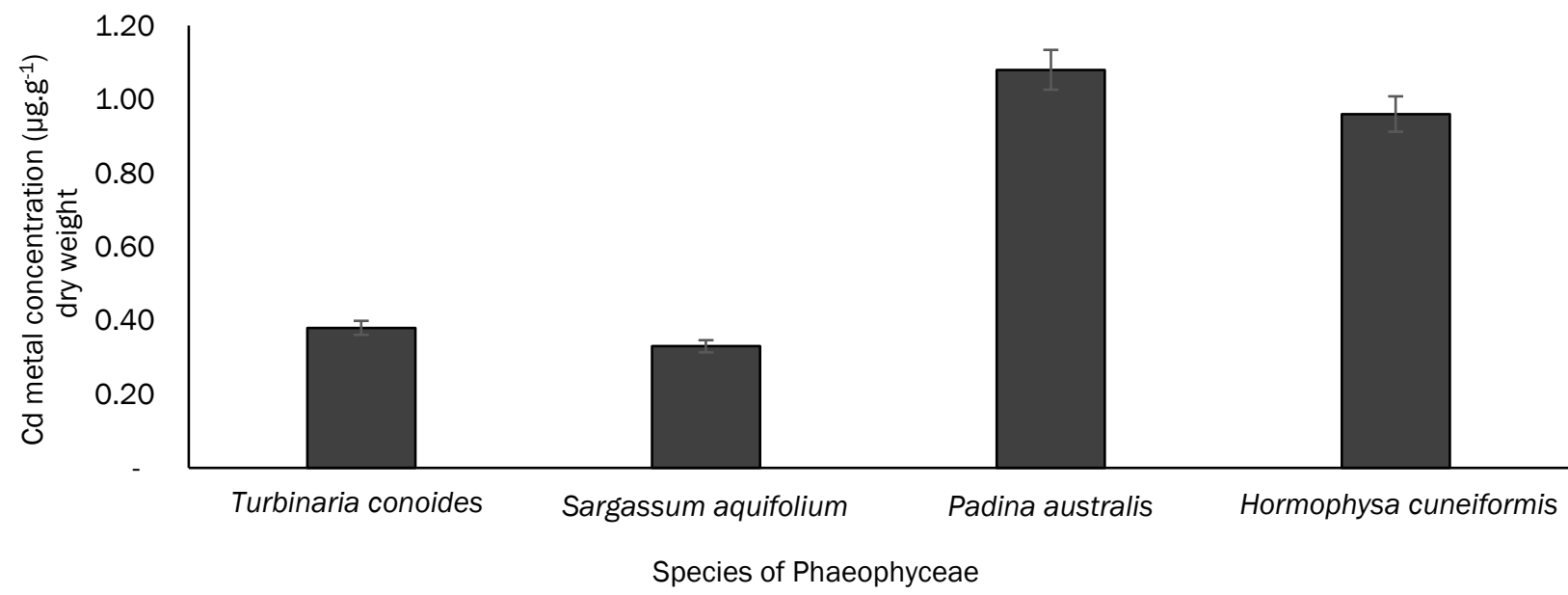

Figure 3. Content of Cd heavy metal in several of Phaeophyceae from Malang Rapat waters

It means the sample was not safe yet to use as raw materials for alginate production or other food processing. $\mathrm{Pb}$ contamination could have comes from mining, oil, and gas burning activities (Agustina, 2014). Excess $\mathrm{Pb}$ in the human body will lead to the cause of disturbances in the nervous system, kidney work, hematologic, and hemotoxic (Suhendrayatna, 2001).

Macroalgae can be contaminated with heavy metals through the intake that enters their environment where it lives. This is because their properties were easy to bind with organic matter, settle in the waters, and unite with sediments (Ismarti et al., 2017). Macroalgae, which are benthic organisms and are attached to the bottom of the waters and their body parts were called a thallus (Suparmi and Sahri, 2009), live by absorbing minerals from their environment through their body surface (thallus). Therefore, mineral substances mixed with heavy metal contamination are also absorbed by the thallus. Therefore, macroalgae can accumulate heavy metals in their bodies or what is called a bio-accumulator (Cordova and Muhtadi,
2017), and it becomes an indicator for bio-monitoring to determine the level of heavy metal contamination (Ismarti et al., 2017) in a water area.

The concentration of metal contaminants in Phaeophyceae can be seen in Table 2, which showed the different levels of heavy metal concentration. This is related to the different intake amount of heavy metal in each macroalga in the waters. This also happened to the research conducted by (Ismarti et al., 2017) was shown the same matter. This study also showed that As metal contamination has the greatest concentration compared to others. This is because the region of Bintan is an area where is active in mining activities such as bauxite, granite, and quartz sand (Irawan, 2013; Rositasari, 2016). Whereas As or arsenic, contamination is caused by many natural resource exploration activities such as mining. The entry of arsenic into the waters can come from mining activities, metal smelting, factory activities, and power generation (Suhendrayatna, 2001). According to Brunori et al. (2005), Grafe et al. (2011), Heavy metal contaminants such as As, Cr, Ni, 


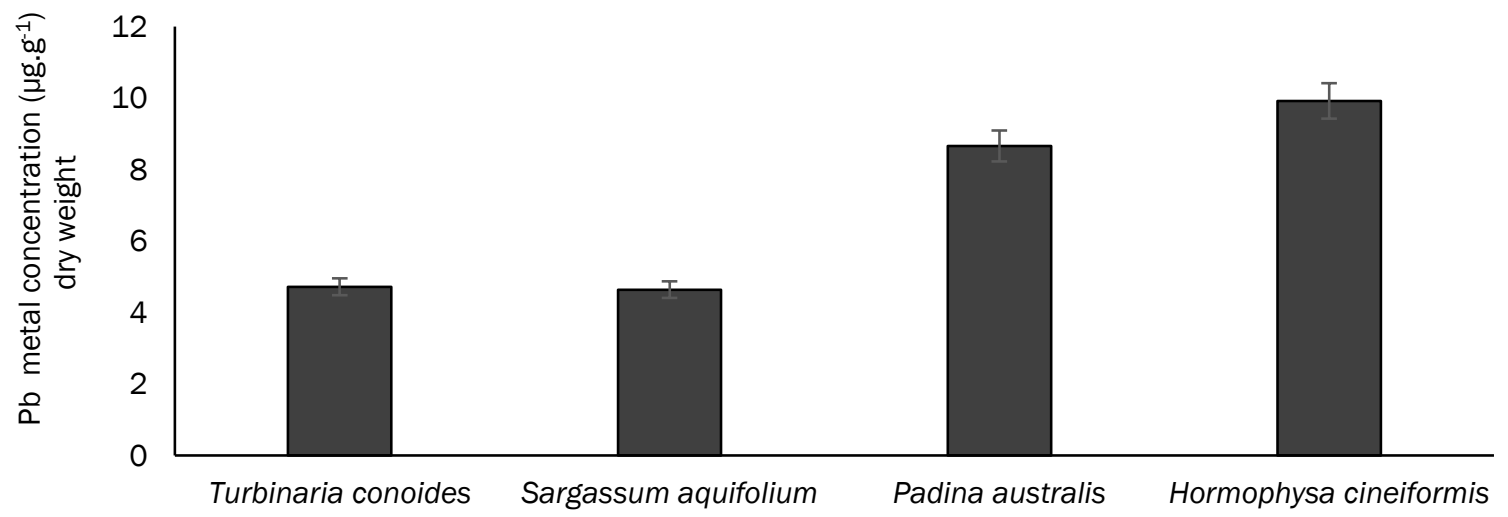

Species of Phaeophyceae

Figure 4. Content of $\mathrm{Pb}$ heavy metal in several of Phaeophyceae from Malang Rapat waters

Table 2. Heavy metals concentration level (mean \pm SD) in several of Phaeophyceae were found in Malang Rapat Waters

\begin{tabular}{cccc}
\hline $\begin{array}{c}\text { Species of Phaeophyceae were found in Malang Rapat- } \\
\text { Bintan waters }\end{array}$ & $\begin{array}{c}\text { As }\left(\mu g \cdot g^{-1}\right) \text { in dry } \\
\text { weight }\end{array}$ & $\begin{array}{c}\text { Cd }\left(\mu g \cdot g^{-1}\right) \text { in dry } \\
\text { weight }\end{array}$ & $\begin{array}{c}\text { Pb }\left(\mu g \cdot g^{-1}\right) \text { in dry } \\
\text { weight }\end{array}$ \\
\hline Turbinaria conoides & $23.30 \pm 0.81$ & $0.38 \pm 0.01$ & $4.72 \pm 0.89$ \\
Sargassum aquifolium & $15.96 \pm 0.27$ & $0.33 \pm 0.01$ & $4.64 \pm 1.12$ \\
Padina australis & $13.95 \pm 1.48$ & $1.08 \pm 0.39$ & $8.66 \pm 1.99$ \\
Hormophysa cuneiformis & $14.80 \pm 0.16$ & $0.96 \pm 0.18$ & $9.92 \pm 7.10$ \\
\hline
\end{tabular}

$\mathrm{Pb}, \mathrm{Mo}, \mathrm{V}$ can occur in bauxite mining activities at the tailings process stage. Cd can also be found in smallscale bauxite mining (Putra and Apriadi, 2018).

All the samples showed their amount of metal contamination concentration were above the threshold issued by National Standardization Agency of Indonesia No. 7387 of 2009 about concerning the limit of heavy metal contamination in food (National Standardization Agency of Indonesia, 2009) and National Agency of drug and Food Control of Republic of Indonesia No. 5 of 2018 about concerning the maximum limit of heavy metal contamination in processed food (National Agency of drug and Food Control of Republic of Indonesia, 2018) so that the utilization of macroalgae from these waters for alginate production or other food processing is not safe yet and needs further research so that the informations are more diverse. Environmental maintenance matters from the government, business, and society to prevent further pollution must be done so that the negative impact of pollution can be minimized, with the hope that all natural resources in the waters of Malang Rapat Bintan can be safely utilized.

\section{Conclusions}

Phaeophyceae were found in the waters of Malang Rapat-Bintan were Turbinaria conoides, Sargassum aquifolium, Padina australis, Hormophysa cuneiformis were found above the threshold according to the National Standardization Agency of Indonesia No 7387 of 2009 about concerning the limit of heavy metal contamination in food (National Standardization Agency of Indonesia, 2009) and National Agency of drug and Food Control of Republic of Indonesia No. 5 in 2018 about concerning the maximum limit of heavy metal contamination in processed food (National Agency of drug and Food Control of Republic of Indonesia, 2018). This indicate the utilization of those Phaeophyceae were not safe yet to be use as raw material for alginate or other food processing. It is recommended periodically to monitor and evaluate the coastal environment so that the process of controlling contamination can be controlled and the prevention of pollution in the environment can be adequately handled which will lead to the safety of natural resources.

\section{Acknowledgment}

The authors also acknowledge the financial support from Riset Prioritas (COREMAP-CTI Program), Research Center for Oceanography-LIPI No: B5006/IPK.2/KP.06/I/2019 for the research and publication support.

\section{References}

Agustina, T. 2014. Heavy Metal Contamination of Food and Its Impact on Health (In Bahasa). Teknobuga 1(1): 53-65. doi: 10.1529/jtbb. v1i1.6405 
Atmadja, W.S. 1996. Introduction to the Types of Indonesian Seawed (In Bahasa): Atmadja, W.S., Ahmad, K., Sulistijo., Rachmaniar, S., (Eds.). Puslitbang Oseanologi LIPI ISBN 979-8105-46X. Jakarta. p:91.

Bowen, D.A. 2009. Food Safety Series-Accurate Analysis of Low Levels of Mercury in Fish by Vapour Generation AA. Thermo Fisher Scientific, Cambridge, UK. p:6.

Cordova, M.R. \& Muhtadi. 2017. Screening of Mercury Absorption in Brown Macroalgae Hormophysa triquetra and Red Macroalgae Gracilaria salicornia from Pari Island (In Bahasa). Oseanologi dan Limnologi di Indonesia. 2(3): 25-33. doi: 10.14203/oldi. 2017.v2i3.93

Gazali, M., Nurjanah. \& Zamani, N.P. 2018. Exploration of Brown Algae Bioactive Compounds on Sargassum sp. Agardh as an Antioxidant from the West Coast of Aceh (In Bahasa). J. Pengolahan Hasil Perik. Indonesia, 21(1): 167-178. doi: 10.17844/jphpi.v21i1. 21543

Irawan, A.B. 2013. Valuation of the Carrying Capacity of the Protection Function in Bintan Island, Riau Islands Province (In Bahasa). J. Sains dan Teknol. Lingkungan. 5(1): 48-65. doi: 10.20885/jstl.vol5.iss1.art6

Ismarti., Ramses., Amelia, F. \& Suheryanto. 2017. Study of Heavy Metal Content in Plants from the Waters of Batam, Riau Islands (In Bahasa). Dimensi. 6(1): 1-11. doi: 10.33373/dms. v6i1.543

Maharani, A.A., Husni, A. \& Ekantari, N. 2017. Effect of Extraction Methods on Characteristic of SodiumAlginate from Brown Seaweed Sargassum fluitans (In Bahasa). J. Pengolahan Hasil Perikan. Indo., 20(3):478-487. doi: 10.17 844/jphpi.v20i3.19768

Manalu, F.L. 2017. Study of the Heavy Metal Content of Lead $(\mathrm{Pb})$, Cadmium (Cd), Chromium (Cr), Copper (Cu), and Manganese (Mn) in Seaweed (Sargassum sp.) in the Coast of Lampung Bay Using Atomic Absorption Spectrophotometry (In Bahasa). Thesis. Mathematic Faculty and Science, University of Lampung, Bandar Lampung. p:71.

Mulyadi, A., Yoswaty, D. \& Ilahi, I. 2017. Environmental Impact of the Development of Marine Ecotourism in the Trikora Bintan Seagrass Conservation Area, Riau Islands (In Bahasa). Berkala Perikanan Terubuk, 45(1): 95111. doi: 10.31258/terubuk.45.1.95.20.20 111
National Agency of Drug and Food Control of Republic of Indonesia. 2018. Maximum Limit of Heavy Metal Contamination in Processed Food No 5 (In Bahasa). National Agency of Drug and Food Control of Republic of Indonesia. Jakarta. p:8.

National Standardization Agency of Indonesia. 2009. Maximum Limit of Heavy Metals Contamination in Food (In Bahasa). No 7387. National Standardization Agency of Indonesia. Jakarta. p:25.

Pakidi, C.S. \& Suwoyo, H.S. 2016. Potential and Utilization of The Active Ingredient of Brown Algae (Sargassum sp) (In Bahasa) Octopus. 5(2): 488-498.

Parreidt, T.S., Múller, K. \& Schmid, M. 2018. AlginateBased Edible Films and Coatings for Food Packaging Applications. Foods. 7(170): 2-38. doi: $10.3390 /$ foods 7100170

Prasetyaningrum, A. \& Purbasari, A. 2002. Alginate Extraction from Seaweed and Its Application in Industry. Reaktor. 6(2): 63-67. doi: 10.14710/ reaktor.6.2.63-67

Putra, R.D. \& Apriadi, T. 2018. Study of Heavy Metal Contamination ( $\mathrm{Pb}$ and $\mathrm{Cr}$ ) after Bauxite Mining as a Potential Location for Aquaculture Activities. Intek Akuakultur, 2(1):1-15. doi: 10. 31629/intek.v2i1.273

Rohmana, Djunaedi, E.K. \& Pohan, M.P. 2007. Inventory of minerals from ex-mines in the Bintan Island area, Riau Islands Province (In Bahasa). Proceeding Pemaparan Hasil Kegiatan Lapangan dan Non Lapangan, Pusat Sumber Daya Geologi, 1-14.

Rositasari, R. 2016. Bintan is a Wonderful Island (In Bahasa). Oseana. XL(4):15-24.

Setiawan, H. 2013. Accumulation and Distribution of Heavy Metals in Mangrove Vegetation in Coastal Waters of South Sulawesi (In Bahasa). J. IImu Kelautan. 7(1):12-24. doi : 10.22146/jik.6134

Suhendrayatna. 2001. Bioremoval Heavy Metals Using Microorganisms: a Literature Review (In Bahasa). Seminar for 21st Century Indonesia, Sinergy Forum-PPI Tokyo Institute of Technology. p: 9.

Suparmi \& Sahri, A. 2009. Recognizing the Potential of Seaweed: Study of Seaweed Utilization Resources from Industrial and Health Factors (In Bahasa). J. Sultan Agung. XLIV (118): 95-116. 